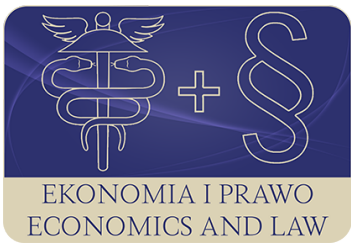

EKONOMIA I PRAWO. ECONOMICS AND LAW

Volume 19, Issue 3, September 2020

p-ISSN 1898-2255, e-ISSN 2392-1625

www.economicsandlaw.pl

ORIGINAL ARTICLE

received 22.11.2019; revised 20.01.2020; accepted 30.09.2020

Citation: Rudolf, S. (2020). Attempts to harmonise the European Union legislation in respect of employee representation in corporate governance bodies. Ekonomia i Prawo. Economics and Law, 19(3): 533-549. doi:10.12775/EiP.2020.036.

\title{
Attempts to harmonise the European Union legislation in respect of employee representation in corporate governance bodies
}

\author{
STANISLAW RUDOLF \\ WSB University in Gdansk, Faculty of Finance and Management, al. Grunwaldzka 238A, \\ 80-266 Gdańsk, Poland \\ ๑ srudolf@wsb.gda.pl \\ Dorcid.org/0000-0002-3292-3243
}

\begin{abstract}
Motivation: Representation of employees in corporate governance bodies is, on the one hand, an important element in the democratisation of labour relations, while on the other hand, it can bring notable positive benefits to businesses. It is standard practice in a decided majority of the old EU countries, but only to a limited extent does it function in the countries which joined the EU in 2004 and later.

Aim: The author of the article has defined two important goals. The first one is to present solutions concerning employee representation in individual EU countries. The second goal is to present earlier attempts to harmonise the EU legislation on the matters of such representation and to indicate the possibility of such harmonisation under the current conditions.
\end{abstract}

Results: What has been noted in the article is that as many as 10 EU countries have no legislation concerning employee representation in corporate bodies. Although such legislation exists in other countries, the implemented solutions are heavily diversified. It has also been evidenced that the past attempts aimed to harmonise this sphere have generally failed. Against such background, establishing what is commonly referred to as a European Company with employee representation in its corporate governance bodies should be considered as a success, but due to a very limited range of such companies, it is but a par-

tial success. 
Keywords: corporate governance; BLER; European Company

JEL: G34; M54

\section{Introduction}

The participation of employee representatives in corporate governance bodies is an important element of labour relations in the European Union countries. Such representation is considered as one of indirect forms of participation, as they are referred to, since it is the employees who nominate their representatives to the company's strategic decision-making bodies. Employee representation in these bodies is the very essence of the concept of BLER (board-level employee representation). In Western literature of the subject, BLER is understood as 'representation of employees in any model of governance as long as employees have the right to be represented in the strategic decision making body of the company' (Munkholm, 2018, p. 1). In the two-tier governance model, this translates into employee representation in the supervisory board, while in the one-tier model - representation in the board of directors or in the company's management board. It also means that the BLER concept does not comprise the rights of employees and their bodies in the scope of information and consultation ${ }^{1}$, or their rights in the scope of occupational health and safety ${ }^{2}$.

In accordance with the EU legislation, the scope and forms of employee participation in corporate bodies are determined by the Member States. This means that there is no single European BLER model applicable to all these countries. The principles of employee representation in strategic corporate bodies may be stipulated by both corporate law and labour law. In most countries, e.g. in Germany and Denmark, they are covered by the company law, while in Austria, for instance, they are to be found in the labour law. The manner in which this form of representation is regulated in the applicable laws is not without significance from the perspective of law enforcement in this respect. In the former case, compliance with the law is considered in the context of the balance of benefits and costs of such representation. There may be resistance from those employers who recognise the impact of such representation on the given company's economic performance as negative. It should also be noted that each employer should naturally abide by the law in force, even if it entails certain costs. In the latter case, labour law must be strictly observed as it constitutes the fundamental legal basis.

Employee representation in corporate bodies was a controversial issue from the very onset of the related discourse. Hence the clear division into keen supporters of the BLER concept and its opponents. The latter are mainly employers and their organisations at the EU level. A group of five such organisations is represented in the European Economic and Social Committee, an authority

${ }^{1}$ Directive 2002/14/EC (2002) marked significant progress in the dissemination of these rights.

2 In this scope, employee rights are defined in Directive 89/391 (1989). 
issuing opinions on certain proposals which are then submitted to the EU decision-making bodies. Employers are reluctant to share power with their employees as they believe that those who represent employees on councils represent primarily the interests of those who have appointed them, instead of the businesses' interests. The evidence to the foregoing should be found in the opposition to downsizing or in the disclosure of information obtained from board meetings. One of the most frequently mentioned reasons for such an attitude of employers towards BLER is also the conviction that, in general, employees are poorly prepared to performing their duties on respective corporate bodies compared to the competencies of the employers' representatives.

On the other hand, trade unions seek to expand BLER, since what they have noticed in such a representation form is an additional channel enabling them to obtain information as well as to increase the possibility of actually influencing the company's operations. It is no secret that there are generally close links between trade unions and staff representatives in corporate governance bodies. Trade unions usually exert major influence on the appointment of such representatives, while in some countries they actually nominate them by themselves (Berglund et al., 2013, p. 4). Consequently, the vast majority of these representatives are union members, which is why one can usually observe close cooperation between them, considered beneficial for both these parties. Trade unions often use staff representatives having a seat on corporate bodies to pursue the goals that they cannot otherwise achieve by traditional means. Staff representatives, on the other hand, welcome the information and experience as well as the support provided to them by trade unions. One of the most eager advocates of the concept to extent such a form of representation, including development of a single BLER model for the entire EU, is the European Trade Union Confederation (ETUC, 2014).

The aforementioned controversies concerning employee representation in corporate governance bodies, as well as the conditions which should be taken into account in individual EU countries give rise to a wide variety of solutions. The goal of this study is to discuss the existing scope of such representation form in individual countries, as well as to present the endeavours made by the EU authorities aimed at its unification. In the conclusions, the author has attempted to identify the possibilities for creating a single European law concerning such a form of participation.

\section{Literature review}

The aforementioned controversies concerning the BLER concept are the decisive factors underlying the popularity of this problem among authors. Publications addressing this area may basically be divided into two groups. One includes publications prepared by officers of the EU institutions. The range of these publications is very extensive, and they include annual reports concerning the scope of such representation in individual countries as well as the results of empirical 
research conducted by these institutions. This group also comprises theoretical considerations on the place of such representation in the power structure of businesses with reference to such theories as the agency theory or the stakeholder theory.

The second group includes BLER-related publications produced in individual countries. These are typically critical analyses of the conditions under which such a form of representation functions, and they provide some proposals for its extension. They also discuss the results of empirical studies conducted in individual countries. Although focused on national problems, many of these publications refer to general problems or theoretical considerations.

Many of the publications comprising the first group were developed by the EU institutions, such as the European Foundation for the Improvement of Living and Working Conditions and the European Trade Union Institute (ETUI). The former of these institutions concentrated on studying the representation form in question and on publishing papers of both theoretical and empirical nature. It was there that such important papers as Worker directors: a comparative study of five countries were published (Carley, 1997), summarising the extensive empirical research concerning this subject which had been performed in the EU countries, or the publication entitled Industrial relations developments in Europe 2005 (EIRO, 2007). This subject was also extensively elaborated at ETUI, releasing such papers as, for instance, annual reports on employee representation in individual countries and scientific articles, mainly published in the Transfer journal (Carley, 2005). In its publications, the said Institute, founded by the European Trade Union Confederation, sought to disseminate the idea of employee representation in corporate governance bodies (Kluge \& Wilke, 2007).

Many publications addressed the BLER-related situation in individual countries. They were dominated by discussions on the results of empirical studies on the perception of BLER among both workers and their trade unions and employers, including in countries where no such form of representation is envisaged. They included e.g. the Dutch experience (Goodijk, 2018), representing a country where an extensive discussion was held on the impact of employee representation on making strategic decisions in businesses. Many publications on this subject were published in Scandinavian countries, e.g. those addressing the problem of including staff representatives on the board of directors under the one-tier system (Levinson, 2001). This issue was also addressed by British authors, even though there is no BLER legislation in the UK. What they studied was the individual forms of participation in employee-owned businesses, commonly referred to as ESOPs, comparing them with conventional companies representing the same industry (Pendleton et al., 1996). Polish authors have addressed this problem to a significantly lesser extent. What deserves to emphasised in this respect is the report on research concerning employee representation on supervisory boards of companies (Rudolf, 1996) and several other publications by this author. 
Publications commenting upon BLER focus mainly on the existing solutions applied in this area in individual countries. However, rarely do the authors analyse the possibilities of harmonising such solutions.

\section{Methods}

The method used by the author to fulfil the aforementioned research objectives was critical analysis of the literature of the subject. The analysis covered such texts as those published in recognised journals of industrial relations (European Journal of Industrial Relations, Industrial Relations Journal, Historical Studies in Industrial Relations). The problems in question were analysed from the legal perspective (International and Comparative Law) and the social perspective (Work, Employment and Society). These literature references were assumed to help in determining the degree of diversity in terms of the solutions implemented in individual countries. What has also been discussed in the study is the potential for adopting the BLER legislation in countries where no such legislation exists. In an attempt to define the characteristics of the attempts made by the EU authorities to harmonise BLER in the Member States, respective legal regulations concerning this problem have been used, and the process of creating such regulations has been tracked.

\section{Results}

\subsection{Current legal status of employee representation in corporate bodies}

As aforementioned, the solutions implemented in respective countries with regard to the problem of employee representation in corporate bodies are very diverse in nature. At one extreme there are countries where this form of participation is secured by laws, even in the constitution, in certain cases, while at the other extreme there are countries where, even if it exists in some form, such representation is not legally regulated. This analysis begins with countries where staff representatives have their seats in corporate bodies secured under the relevant legislation.

\subsubsection{EU countries with BLER statutorily secured}

In $18 \mathrm{EU}$ countries, staff representatives are vested with the statutory right to participate in corporate governance bodies. However, this right is not uniform and the scope of such representation is most frequently determined by factors such as company ownership, structure of corporate authorities, company size, strength and position of trade unions, etc. In practice, each of these countries has implemented a different system of participation, although some 
of them share individual features. It is these similarities that Waddington \& Conchon (2016) used to distinguish between four BLER categories. The successive categories defined under this classification are characterised by an increasingly broad scope of employee representation. Gold \& Waddington (2019, pp. 205-218) added the fifth category. This division has been adopted further on in this paper ${ }^{3}$.

\subsubsection{First category of BLER}

The first category applies to 3 countries, namely: Ireland, Greece and Spain. These are the countries with the most limited scope of BLER. The existing legislation concerning this matter is limited only to certain state-owned enterprises. The privatisation processes implemented in these countries reduced the scope of state ownership in the recent years, and consequently also the scope of employee representation. The 2008 financial crisis further narrowed down this scope. Even so, the aforementioned legislation has not been amended and remains binding. The one-tier corporate governance model applies all these countries. One can find the employee representation on the board of directors to be most extensive in Ireland, as it accounts for $1 / 3$ of the board's composition. In Spain, on the other hand, the board includes two staff representatives. This type of representation is most limited in Greece, as only one person on the board is envisaged.

\subsubsection{Second category of BLER}

The authors include France and Poland under this category. In these countries, the employee representation in corporate bodies is not limited to the public sector only, but it also functions in the private sector to some extent. These countries differ from each other in terms of the corporate governance model typically used, since the two-tier model applies in Poland, while French companies can choose between the one-tier and the two-tier model. The French legislation provides a guarantee to the personnel that one or two of their representatives hold a seat in the board of privately owned companies with more than 1,000 employees (more than 5,000 employees outside France). In Poland, on the other hand, the act of 1996 stipulates that employees are represented by two persons appointed as members of a five-person supervisory board in stateowned companies. Such representation is not cancelled once the state has sold even all its shares to private investors. The act defines the number of such staff representatives to range between 2 and 4 persons, this being conditional to the size of the board. The privatisation processes implemented in Poland have resulted in a numerical decline in the employee representation from more than 1,000 persons in 2003 to ca. 400 in 2011 (Conchon, 2012).

3 The analysis of these categories has been based on such sources as: Gold \& Waddington (2019), Munkholm (2018) and Ozsvald (2014). 


\subsubsection{Third category of BLER}

The third of the aforementioned categories comprises the following 5 countries: Croatia, Czechia, Finland, Luxembourg and Slovakia. In these countries, the staff is represented on boards of all companies of the public sector as well as in private companies which have exceeded a certain headcount threshold. This threshold is relatively low in the Czech Republic and Slovakia with 50 employees, it is higher in Finland, where it is 150 employees, in Croatia - 200 employees, while it is the highest in Luxembourg, as it equals 1,000 employees. These countries differ in terms of the corporate governance model in place. The twotier model has been implemented in Czechia and Slovakia, while the remaining countries admit both the two-tier and the one-tier model. This category is dominated by new EU countries. It is in these countries that the pending privatisation processes have effectively limited the employee representation on company boards. Moreover, pursuant to the laws of 2014, such representation in private companies was further limited in the Czech Republic. Employees are least represented on company boards in Croatia, where only one representative is secured, while in other countries under this category they account for at least 20\% of the board composition.

\subsubsection{Fourth category of BLER}

This category includes 6 countries, namely: Austria, Denmark, Germany, Hungary, Slovenia and Sweden. These are the countries with the most extensive employee representation. Their BLER legislation applies to the entire economy. Nevertheless, the corporate governance structure in this group varies as well. Only Sweden has implemented the one-tier governance model. In Austria and Germany, the two-tier model prevails. In other countries, companies can choose between the one-tier and the two-tier model. It should also be noted that the two-tier model had been in force by 2010 in Hungary and Slovenia, while the one-tier model used to apply in Denmark. Also the BLER applicability thresholds vary, ranging from 25 employees in Sweden to 500 employees in Germany. There are also significant differences in terms of the scope of employee participation on company boards. The most limited, one-man representation model applies in Slovenia, while the most extensive model is the German one, where employee representation is up to $50 \%$ of the board composition.

\subsubsection{Fifth category of BLER}

The last category comprises the Netherlands, where the BLER solutions differ significantly from other countries. This is a country where staff representatives on the supervisory board are nominated by this board at the request of the works council. They may account for up to 1/3 of the supervisory board composition. The supervisory board is also entitled to propose such members on its own initiative, in which case the works council can exercise the right of veto. The staff 
representatives are not necessarily employees of the same company. They may be academics as well as experts in finance, law or labour relations (Kaarls \& Poppema, 2018).

In summary of this section of the study, it should be noted that in terms of the implemented BLER related solutions, various countries differ significantly from one another. This is partly due to the corporate governance model applied in the given country. The two-tier model is definitely more suited for employee representation, as it perceives the board of directors as a natural space for such representation. For a long time, the one-tier model would rule out such representation on the board of directors, and not until the recent decades could any changes in this respect be observed. They are oriented towards two targets: representatives of the personnel (or trade unions) are either placed on the board, which is the case of Sweden (Berglund et al., 2013), or companies may choose between the one-tier and the two-tier model. Where the latter is the case, employees are represented in company boards (in either the board of directors or the supervisory board) under each of these models. It should be added that the employee representation on the board of directors is typically more limited. However, employee representation on the company's management board is a rarity.

Another conclusion one may formulate is that the changing BLER related legislation is headed for opposite directions in different countries. On the one hand, such form of participation is being limited in scope, which is particularly evident in the new EU countries (Czechia, Slovakia, Poland). This process has intensified over the recent years under the influence of the financial crisis and the ongoing privatisation processes. It is also related to the apparent weakness of the trade unions, which were unable to resist the pressure imposed by employers and their organisations. On the other hand, one can observe the process of extending the scope of staff representation on corporate bodies by placing employees in boards of directors. According to such authors as Gold \& Waddington (2019), the latter of these processes is more frequent than the former.

\subsubsection{EU countries without BLER statutorily secured}

The notion of employee representation in corporate governance bodies is not as popular as it may seem. In as many as 10 EU countries there is no legislation in place to guarantee that employees are represented on the supervisory board (under the two-tier model) or on the board of directors (under the onetier model). These include both the so-called old EU countries (Belgium, Italy, the United Kingdom), and some new countries, which come in a significantly greater number (Bulgaria, Cyprus, Estonia, Latvia, Lithuania, Malta, Romania). If one can speak of any forms of such representation in these countries, they result from voluntary agreements made at the corporate level exclusively. For instance, these may be agreements between employees or their trade unions 
and the company's management board ${ }^{4}$. The rules of such a form of representation may be stipulated in such covenants as the articles of association, etc.

Those countries differ from each other in terms of the corporate governance model in place, their respective traditions of participation, as well as the power and position of trade unions, etc. This makes the chances of introducing the BLER legislation in these countries highly disparate. The one-tier corporate governance model prevails in these countries, while it is mandatory in four of them (Belgium, Cyprus, Malta, UK). In the remaining four, companies can choose between the one-tier and the two-tier model (Italy, Bulgaria, Lithuania, Romania). Only two countries have implemented the two-tier model (Estonia, Latvia). Assuming that the two-tier model is more favourable to employee representation on the supervisory board, it has been made available in 6 countries. This implies that the corporate governance model should not constitute a significant obstacle to the implementation of the BLER legislation.

In some of the aforementioned countries, employees are granted the right to participate in the proceedings of corporate bodies under certain circumstances. In Estonia, for instance, the management may invite staff representatives to shareholders' meetings. In Bulgaria, staff representatives can vote at the general meeting of shareholders of companies with the headcount of more than 50 persons. This option was formally introduced in 2003 in light of the country's preparations for accession to the EU. In Romania, representative trade unions are entitled to participate in board meetings without the right to vote when economic, social and culture-related problems are discussed.

This is not the case of Cyprus and Malta. These countries have abandoned the BLER legislation in the recent years. In Cyprus, this was due to the employers' strong resistance. And although the efforts of the European Trade Union Confederation had led to placing staff representatives on the boards of two major banks in 2006 and 2007, this solution was soon abandoned after the financial crisis. In Malta, nationalist party governments decided to drop BLER. This led to increasingly serious confrontations between the government and the local trade unions, ultimately causing the BLER concept to be abandoned. An impact on this state of matters was also exerted by privatisation processes.

In countries such as Belgium, Italy and the United Kingdom, attempts were or are being made to introduce BLER. In Italy, employee representation on company boards was introduced past 1945, and it was subsequently expanded. However, due to the growing resistance from employers and the competition between trade unions, this principle was suspended in 2003. In Belgium, employees are represented on boards of directors of certain state-owned enterprises, and there is currently a heated discussion concerning BLER. In 2017, a proposal for employee representation on the boards was included in the agenda of the Flemish Green Movement. In the same year, the Socialist Party made official proposals of similar substance. In the authors' opinion, although these parties are cur-

${ }^{4}$ One can come across such a solution in certain public sector enterprises operating in Belgium and Italy. 
rently not in power, their proposals may still encourage discussion concerning BLER (Ferreras, 2017).

The BLER discourse has continued for the longest in the United Kingdom, and it was triggered by the Bullock Report released in 1977. A year later, the Labour Party government published a White Paper with an implication that companies should negotiate detailed BLER solutions with trade unions. However, in the event of disagreement on this matter, an optional solution was to be introduced, assuming a two-tier governance model with staff representatives holding $1 / 3$ of the seats in the supervisory board ${ }^{5}$. It was also at that time that the first employee directors of state-owned companies (British Steel, Post Office, etc.) were appointed. The conservative government formed in 1979 cancelled the employee directorship scheme, thus virtually ending the discourse on this subject in practical terms. Not until the time of Prime Minister Theresa May was this issue addressed. In 2016, her administration released a publication referred to as the Green Paper, entitled Corporate governance reform (Gold \& Waddington, 2019). However, among the four alternative solutions proposed, one can hardly find any significant implications concerning BLER itself. They practically boil down to a single representative of the staff holding a seat on the board.

The remaining countries analysed in this study, i.e. Lithuania and Latvia, have no experience in this sphere. This does not mean that there can be no solutions introduced on a voluntary basis in individual companies. In this respect, they may also refer to some historical experiences from the previous political systems.

\subsection{Attempts to harmonise BLER by the EU authorities}

The participation of personnel members in corporate bodies can hardly be analysed without considering the company law. Various authors (Enriques, 2017, pp. 763-777; Gelter, 2018) agree that since the very beginning of the concept in question, i.e. since the 1950s onwards, numerous attempts at harmonisation of the company law have been made, including those aimed at harmonisation of employee representation in corporate governance bodies. Their purpose has been to create a single European market.

Initially, the situation was rather favourable to the harmonisation of BLER. Up till 1972, three of the then six Member States, namely France, Germany and the Netherlands, supported this endeavour. The harmonisation would allow for the workers' rights applicable in the Member States to be made uniform with regard to important areas of the strategic decisions made by businesses. There can be no doubt that it was by far the best time to conduct such harmonisation. What was missing, however, was adequate determination to pursue this goal. If such an attempt had been successful, the countries accessing the EU

${ }^{5}$ According to Gold (2005, pp. 29-65), such governmental actions were largely induced by the then European Economic Community. 
would have been forced to accept this state of affairs and adapt their legislation to the European BLER framework.

Bearing the above considerations in mind, one may conclude that the current situation is considerably different. Further countries accessing the EU brought their own distinctive BLER systems, which typically differed from one another to a large extent. All things considered, the effectiveness of the BLER harmonisation processes implemented in the EU may be considered dubious at the least, for one must realise that national corporate governance systems were often developing for decades. Consequently, they resulted from a long-term evolution and a clash of political, social and economic views. At the same time, they are deeply rooted in the respective national institutional frameworks. The harmonisation processes undertaken under such conditions will surely come across strong resistance, mainly from employers and their organisations, but also from certain trade unions or political parties. One could expect particular resistance from those countries where labour relations were not statutorily regulated.

The right to employee representation was mentioned in the Community Charter of Fundamental Social Rights of Workers, signed by the member states (save for the United Kingdom) in 1989 in Strasbourg, constituting a public declaration of the European Community's states and governments. It was included in the section on Information and consultation and participation for workers (European Commission, 1989). The discussion on how to implement the Charter was continued over the following two years. Due to the United Kingdom's opposition, it was ultimately not included in the Treaty of Rome. However, its principles were included in a special Report and an Agreement on social policy supplementing the Maastricht Treaty of 1992. However, the Charter was not legally binding, and the rights it stipulated were not subject to appeal.

It had been for all these aspects that the right to employee representation was ultimately excluded from the Charter of Fundamental Rights of the European Union adopted by the Council of Europe in 2000. This obviously triggered serious consequences, since the lack of provisions on BLER in the Charter prevented this notion from becoming a part of the legally binding Maastricht Treaty which entered into force in 2009. The overall body of BLER related problems was to some extent reflected in the Treaty on the Functioning of the European Union of 2008. It contains a provision on supporting Member States in such matters as employee representation and protection of employees' interests, including in terms of shared decision making (Munkholm, 2018, p. 2).

In a sense, the provisions of the aforementioned Charter had their follow-up in the European Pillar of Social Rights, being an EU document signed by the European Parliament, the Council of Europe and the European Commission in 2017. Paragraph 8 of this document, entitled Social dialogue and involvement of workers, reiterates and supplements the provisions of the Charter. It reads as follows: 'workers or their representatives have the right to be informed and consulted in good time on matters relevant to them, in particular on the transfer, restructuring and merger of undertakings and on collective redundancies' (Eu- 
ropean Commision, 2017). The Pillar is not a legal act, but a selection of basic principles and assumptions. It functions as a guideline for the EU Member States with regard to directions of lawmaking.

At the same time, attempts were made to harmonise BLER at the EU level. In this respect, one may speak of at least two such cases. The first attempt was made by the European Commission in 1970, i.e. in a period when the European Economic Community was still composed of 6 countries. It was then that a draft Statute for a European Company was prepared, modelled after the German law. This draft was amended in 1975, mainly on account of introducing a provision on independent supervisory board members. The works on the statute were then discontinued, which was primarily due to the opposition of the United Kingdom for which such a proposal was unacceptable. The works were resumed after the Single European Market, was established in 1986 as the next stage of European economic integration. This act secured what was referred to as four freedoms of movement: of persons, capital, goods and services.

In 1989, the Commission published a revised draft regulation and a draft directive on the concept of a European Company. Negotiations concerning this draft continued until 2001, which was when the relevant regulations were adopted. They were provided in Directive 2001/86 (2001) as well as in Council Regulation (EC) no. 2157/2001 (2001) on the Statute for a European Company, which entered into force in 2004. The procedures to establish European Companies are very complex and involve significant costs, which consequently translates into a very small number of these entities. In many EU countries, no such company has yet been established.

Much attention in the legislation on European Companies is devoted to employee participation. Detailed provisions on participation are thoroughly substantiated because European Companies are created from entities based in different countries and having different participation systems in place. In accordance with the said Directive, the scope of employee participation in a European Company cannot be narrower than that of the countries where the entities incorporating such a company are based. Respective national laws developed on the basis of this Directive may alleviate the participation requirements to a certain extent. However, the Directive stipulates that a European Company shall not acquire legal personality without having implemented the required forms of participation. What should be stresses in this respect is the fact that stakeholders themselves define the corporate governance model of a European Company, which may be either the two-tier or the one-tier model. By that means, they decide on the form of participation of staff representatives in the governance. This concept differs from earlier solutions of a similar kind, where the given country's legislation would impose the system of employee participation in corporate governance bodies.

Therefore, the European Company is becoming a new type of enterprise with a very flexible system of employee representation in corporate governance bodies. Although the period of more than a dozen years when the regulations on Eu- 
ropean Companies were formally in force did not trigger any dynamic growth of these entities, this process has recently shown significant acceleration ${ }^{6}$. One should note that the European Company concept contributes to the dissemination of the idea of employee representation in corporate governance bodies in countries where no such form of representation exists. One example is the United Kingdom where, for instance, most entities which incorporate European Companies with German entities and are registered in Germany adopt the two-tier model which applies in Germany. This means that representatives of British employees are represented on supervisory boards of the European Companies with the registered office in Germany.

The solutions discussed above, implying harmonisation of the legislation on the EU level, are applied on a voluntary basis and have not attracted much attention yet. The second of the aforementioned attempts was aimed to harmonise BLER across the entire EU on a mandatory basis. A dedicated provision on this subject was included in the draft of the fifth Directive of 1972 concerning the structure of joint-stock companies. In its preamble, much attention is attached to the existing differences in terms of the forms of participation of staff representatives on boards in individual Member States. It advocates elimination of these differences, since they constitute a barrier to the application of Community rules on reorganisation of companies. Of the two corporate governance models implemented in the Member States, i.e. the two-tier model (also called German) and the one-tier model, the former is promoted as it guarantees employee representation on the supervisory boards of companies employing 500 employees and more at 1/3 of the board composition at the least. Another proposal was based on the Dutch system as well as an assumption that changes in the supervisory board would be made on a co-option basis, with the right of veto vested in employee organisations (Kolvenbach \& Hau, 1987, pp. 141-150).

In 1983, i.e. after more than 10 years of heated discussion on the subject, a new and largely altered draft was proposed. Among the new concepts it postulated was the BLER negotiating option and the enterprise size threshold increased to 1,000 employees. On account of the unanimity requirement for the Commission to make a decision, the draft was vetoed by the United Kingdom and ultimately abandoned in 2004. However, this initiative played a significant part in the discourse in progress at that time, especially in such countries as the United Kingdom and Italy. At the same time, it had its fair share in stimulating the European workers' movement.

In recapitulation of this part of the study, one may conclude that the attempts to harmonise BLER across the EU countries have failed. The solutions still applied in individual countries differ considerably from one another. The

${ }^{6}$ According to ETUI (2017), there were 2,827 such companies in 2017, most of which operated in countries such as Germany, the Czech Republic, France, the Netherlands and Austria. They predominantly adopted the two-tier corporate governance model. Within the recent years, however, they have been emerging more dynamically. Over the years 2014-2017, their number increased by more than 700 (Giedrewicz-Niewińska, 2015). 
changes observed in this respect are mainly determined by economic and political factors. One can still speak of the negative impact of the 2008 financial crisis on the extent to which BLER is applied. Earlier, however, when the conditions had been more favourable, the EU had not used the opportunities at hand for the BLER harmonisation, and had confined itself to extremely complex solutions contained in the Statute for a European Company. On account of the voluntary nature of these companies as well as their extremely complicated incorporation procedure, one may expect their number to remain negligible. At the same time, the corporate governance integration processes that one can observe, including those which pertain to codes of good practice, are affected by the increasing competition and the business support schemes introduced by governments, and only to a small extent are they the outcomes of the EU policy.

\section{Conclusion}

The European Commission's efforts aimed at harmonisation of BLER have not yielded the expected results. In other words, it has failed to fulfil its objectives, such as unifying the conditions of competition for enterprises and using the creativity and entrepreneurship of employees to achieve better economic results. Another such objective was to stimulate employee involvement at the workplace, thereby promoting democratic labour relations. Therefore, it may be generally claimed that the BLER harmonisation processes aimed at building a more democratic and successful society and economy. The most serious obstacle turned out to be the opposition of employers and their organisations. Both the position and the influence of the latter across the EU cannot be overestimated. Even certain trade unions as well as governments of individual countries were also opposing such harmonisation.

BLER remains to be perhaps the most controversial form of employee participation. Despite the early German and partly French experiences, BLER was actually consolidated in the 1970s, but this was done primarily to weaken the position of big corporations. It was the best time for BLER harmonisation, but this opportunity was ultimately squandered. The EU enlargement with the countries of Central and Eastern Europe only added to the existing diversity of BLER. At this point, it should be noted that a fair share of the countries which joined the EU after 2004 had not implemented BLER by that time, while other states predominantly patterned themselves after the German model.

The status of BLER in individual EU countries, as explained above, has triggered a change in the perception of the methods of its harmonisation. The opinions that this should not be performed by transplanting the legal framework of one country to another, as it may give rise to understandable resistance and trigger conflicts, are becoming more and more common. Whatever the case may be, one should first thoroughly examine the substance of the law to be introduced by taking into account the power structure in place in the given country, and by determining the way in which legislation and individual decisions 
are made. In the sphere of collective labour law and labour relations, methods and regulations are often inextricably linked with the existing power structures. Consequently, one should agree with Munkholm (2018, p. 11) claiming that changes to the EU legislation on collective labour law and labour relations such as BLER 'should take into account the existing structures, traditions, values and culture of the existing social order and business environment in the Member States'. What is also becoming increasingly popular is the opinion that the European Commission should focus primarily on promoting BLER in the 10 EU countries which have not yet implemented any such solutions.

\section{References}

Berglund, T., Holmen, M., \& Rana, R. (2013). Causes and consequencies of employee representation on corporate boards. Paper presented at the conference 'Twenty Years after Cadbury, Ten Years after Sarbanes-Oxley: Challenges of Corporate Governance', University of Bath, 24-25 June.

Carley, M. (1997). Worker directors: a comparative study of five countries. Dublin: European Foundation for the Improvement of Living and Working Conditions.

Carley, M. (2005). Board-level employee representatives in nine countries: a snapshot. Transfer: European Review of Labour and Research, 11(2). doi:10.1177/102425890501100210.

Conchon, A. (2012). Are employee participation right under pressure? Trends at national and EU level. ETUI Policy Brief, 7.

Council Directive 2001/86/EC of 8 October 2001 supplementing the Statute for a European company with regard to the involvement of employees (OJ L 294).

Council Directive 89/391/EEC of 12 June 1989 on the introduction of measures to encourage improvements in the safety and health of workers at work (OJ L 183).

Council Regulation (EC) No 2157/2001 of 8 October 2001 on the Statute for a European company (SE) (OJ L 294).

Directive 2002/14/EC of the European Parliament and of the Council of 11 March 2002 establishing a general framework for informing and consulting employees in the European Community: Joint declaration of the European Parliament, the Council and the Commission on employee representation (OJ L 80).

EIRO. (2007). Industrial relations developments in Europe 2005. Retrieved 15.01.2020 from https://www.eurofound.europa.eu.

Enriques, L. (2017). A harmonized European company law: are we there already? International and Comparative Law Quarterly, 66(3). doi:10.1017/ S0020589317000239.

ETUC. (2014). Towards a new framework for more democracy at work: ETUC resolution. Retrieved 15.01.2020 from https://www.etuc.org. 
ETUI. (2017). European company (SE) database. Retrieved 15.01.2020 from https://www.etui.org.

European Commision. (2017). European pillar of social rights: building a more inclusive and fairer European Union. Retrieved 15.01.2020 from https://ec.europa.eu.

European Commission. (1989). Community Charter of Fundamental Social Rights: preliminary draft (COM(89)471).

Ferreras, I. (2017). Firms as political entities: saving democracy through economic bicameralism. Cambridge: Cambridge University Press. doi:10.1017/9781108235495.

Gelter, M. (2018). EU company law harmonization between convergence and varieties of capitalism. In H. Wells (Ed.), Research handbook on the history of corporate and company law. Cheltenham: Edward Elgar Publishing. doi:10. 4337/9781784717667.00020.

Giedrewicz-Niewińska, A. (2015). Involvement of employees in corporate governance in a European company. Ekonomia i Prawo. Economics and Law, 14(3). doi:10.12775/eip.2015.021.

Gold, M. (2005). Worker directors in the UK and the limits of policy transfer from Europe since the 1970s. Historical Studies in Industrial Relations, 20. doi:10.3828/hsir.2005.20.2.

Gold, M., \& Waddington, J. (2019). Board-level employee representation in Europe: state of play. European Journal of Industrial Relations, 25(3). doi:10.1177/0959680119830556.

Goodijk, R. (2018). Corporategovernanceand workers' participation in the Netherlands. In R. Markey, P. Gollan, A. Hodkinson, A. Chouraqui, \& U. Veersma (Eds.), Models of employee participation in a changing global environment: diversity and interaction. London: Routledge. doi:10.4324/9781315189284-11.

Kaarls, A., \& Poppema, D. (2018). Netherlands: corporate governance 2018. Retrieved 15.01.2020 from https://iclg.com.

Kluge, N., \& Wilke, P. (2007). Board-level participation and workers' financial participation in Europe: state of the art and development trends. Retrieved 15.01.2020 from https://www.etui.org.

Kolvenbach, W., \& Hau, P. (1987). Handbook on European employee co-management. Deventer-Boston: Kluwer Law and Taxation Publishers.

Levinson, K. (2001). Employee representatives on company board in Sweden. Industrial Relations Journal, 32(3). doi:10.1111/1468-2338.00197.

Munkholm, N.V. (2018). Board level employee representation in Europe: an overview. Retrieved 15.01.2020 from https://eu.eventscloud.com.

Ozsvald, E. (2014). Corporate governance in Central Eastern Europe: a comparative political economy approach. GRINCOH Working Papers Series, 7.03.

Pendleton, A., McDonald, J., Robinson, A., \& Wilson, N. (1996) Employee participation and corporate governance in employee-owned firms. Work, Employment and Society, 10(2). doi:10.1177/0950017096102001. 
Rudolf, S. (1996). Przedstawicielstwo pracownicze $w$ radach nadzorczych spótek (raport z badań). Łódź: Katedra Ekonomii Uniwersytetu Łódzkiego.

Waddington, J., \& Conchon, A. (Ed.). (2016). Board-level employee representation in Europe: priorities, power and articulation. New York: Routledge. doi:10.4324/9781315762388.

\section{Acknowledgements}

Author contributions: author has given an approval to the final version of the article.

Funding: this research was jointly funded by the Research Federation of WSB and DSW Universities.

Note: the results of this study were presented at the conference Corporate Governance and Finance (October 7-9, 2019, Gdansk, Poland). 
